\title{
Structure and wind transport of seasonal snow on the Arctic slope of Alaska
}

\author{
CARl S. BENSON, \\ Geophysical Institute, University of Alaska, Fairbanks, AK 99775, U.S.A. \\ MATTHEW STURM \\ U.S. Army CRREL, Ft. Wainwright, AK 99703, U.S.A.
}

\begin{abstract}
The winter snow on the Arctic slope of Alaska lasts for nine months each year, yet little is known about it from a scientific point of view. Its quantity has been seriously underestimated (by a factor of three) in the weather service records, and the directions and magnitudes of wind-transported snow were unknown before the studies reported here. Our measurements of snow on the tundra indicate two major types which differ in depth, density, overall structure, and thermal characteristics: the veneer facies, lying on and interacting with the tundra, and the drift facies which forms in certain topographic settings. The flux of windblown snow has been determined by repeated measurements on three carefully selected "drift traps", such as river banks, which are large enough so they do not fill during the winter. The measurements span 30 years to show year-to-year variability. The largest transport of snow is from the prevailing easterly winds; about half as much is transported by storm winds from the west. The lowest amount is transported by katabatic drainage winds which flow from the south out of the Brooks Range; they extend a variable, and largely unknown, distance northward onto the Arctic slope before they yield to the stronger easterly and westerly winds.
\end{abstract}

\section{INTRODUCTION}

Seasonal snow covers all of Alaska $\left(1.5 \times 10^{6} \mathrm{~km}^{2}\right)$ for half to three-quarters of the year. This snow differs from the hydrologically important mountain snow of the western United States in that it is colder, steeper temperature gradients occur in it, and there is less of it per unit area. However, it lasts longer and enters more directly into the ecology, including most human activity, as snow itself rather than serving primarily as a coldstorage water reservoir.

Three distinct climatic regions occur within ten degrees of latitude in Alaska as a result of two major mountain ranges which cross in an east-west direction. The Alaskan coastal ranges separate the North Pacific maritime climate from a severe continental climate found in the taiga (boreal forests) of the interior. The Brooks Range separates the interior continental climate from the Arctic polar basin climate (Conover, 1960); the range roughly coincides with the northern limit of trees, so north of it the taiga gives way to tundra.

Each of the three climatic regions contains its own characteristic snow cover (Pruitt, 1970; Benson, 1967, 1969, 1982). Tundra snow, found mainly on the Arctic slope north of the Brooks Range, is wind-packed, dry, and sastrugi-sculpted, with depth hoar at its base. Taiga snow, found in the taiga, between the Brooks and Alaska ranges, is characterized by low-density $\left(<0.2 \mathrm{~g} \mathrm{~cm}^{-3}\right)$, loosely consolidated, depth hoar which makes up most of the snowpack in the lowland brush and forest areas (Trabant and Benson, 1972; Sturm, 1991). Maritime snow, found in and south of the coastal mountains and in the lowlands of southeastern and south-central Alaska, is often deeper than $10 \mathrm{~m}$ and may be wet at low altitudes; snow temperatures are significantly higher than in tundra or taiga snow.

The winter snow on the Arctic slope of Alaska lasts for nine months each year, yet little is known about it from a scientific point of view. Its quantity has been seriously underestimated (by a factor of three) in the weather service records, and the directions and magnitudes of wind-transported snow were unknown before the studies reported here. Since 1961 we have been doing research on taiga and tundra snow. In the taiga snow, much of our attention has been focused on the problem of depth-hoar formation. In the tundra snow, we have attempted to determine the amount of snowfall, the extent of wind transport and deposition, the structure of the snow, its interaction with vegetation, and the mechanisms which govern its melting. This paper deals with the structure and wind transport of snow on the Arctic slope.

Research on tundra snow emphasizes the common ground which exists between seasonal and perennial snow cover. Its wind-swept sastrugi surface strongly resembles the year-round surfaces of the Greenland and Antarctic ice sheets. Our measurements of snow on the tundra indicate two major types: the veneer facies, lying on and interacting with the tundra; and the drift facies, which 

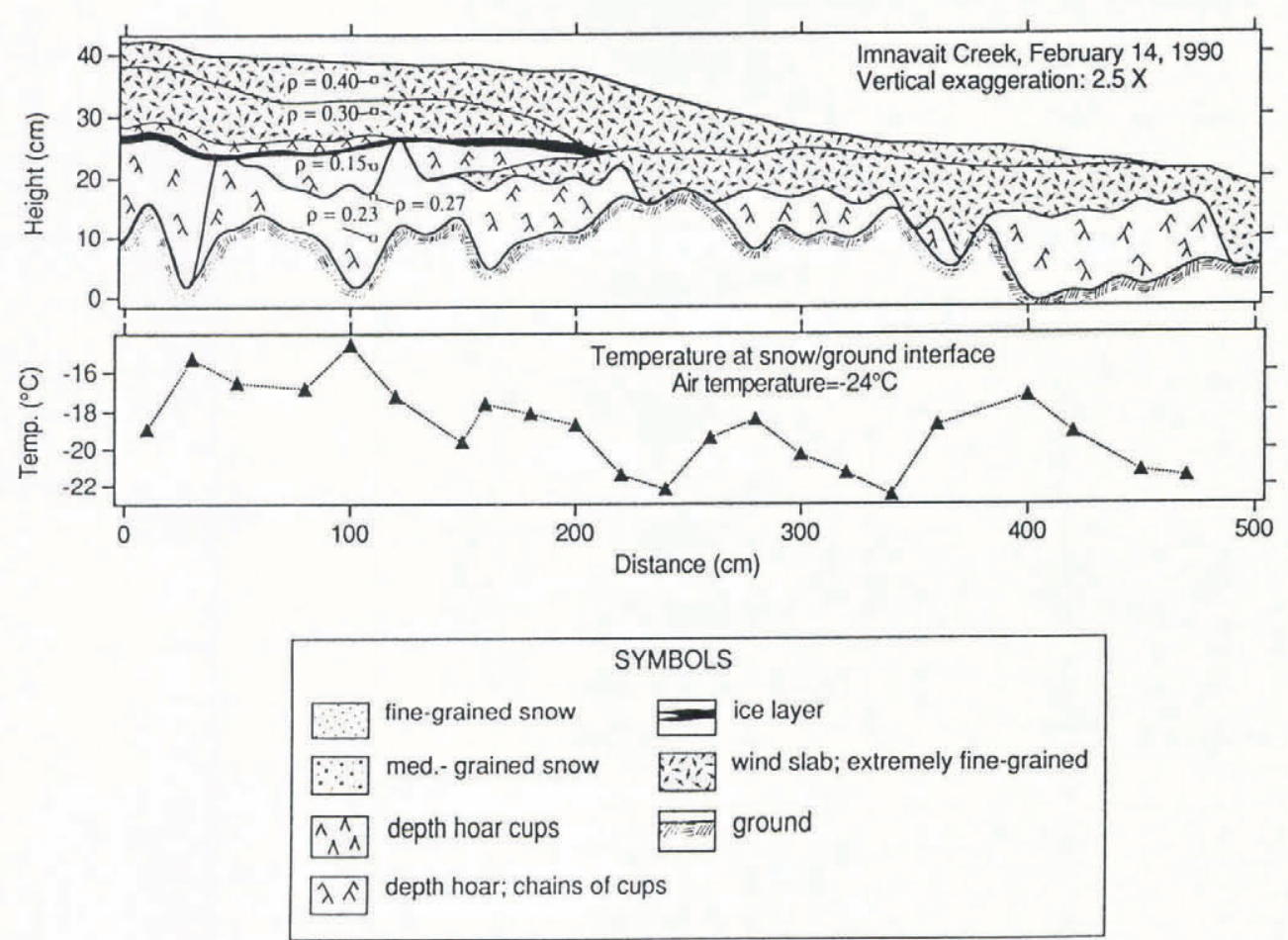

Fig. 1. Typical cross-section through the veneer facies of tundra snow. The tundra tussock relief is a significant fraction of the total snow thickness and strongly affects the snow/ground interface temperature. (NB: cross-sections in Figs 1, 2 and 5 are based on detailed stratigraphic measurements.)

forms in certain topographic settings. The thin veneer of depth hoar and wind-blown snow forms over most flat areas of the tundra. The drifts consist of deeper, denser snow that form in topographic depressions and in the lee of ridges and bluffs. The veneer facies and the drift facies can differ in depth by a factor of 10 and they are radically different in their stratigraphic structure, density and thermal character.

\section{VENEER FACIES OF THE TUNDRA SNOW}

In the veneer facies, the similarity between tundra snow and snow on the polar ice sheets does not stop at the surface. Indeed, the structure of the entire tundra snowpack (however thin it may be) resembles the top annual stratigraphic unit of the perennial dry-snow facies of the Greenland ice sheet (Benson, 1962). It consists of hard, high-density, wind-packed layers, with coarse, lower-density depth-hoar layers at the base. We have studied it by making numerous $5-10 \mathrm{~m}$ long trenches in the snow and observing texture, physical properties and stratigraphy in the excavations (Fig. 1). Although there is considerable variability in the veneer snow, it can be described as a mix of taiga snow with wind-packed tundra snow (Table 1).

The basal depth hoar forms in the first layers of winter snow that are subjected to extremely strong temperature gradients $\left(>1^{\circ} \mathrm{cm}^{-1}\right)$ immediately after deposition and for many months thereafter. It is not unusual to find that the basal depth-hoar layer is laterally discontinuous and icy in places (Fig. 1) because of the control exerted by the micro-topography of tundra vegetation. The net relief of tundra tussocks ranges from 10 to $40 \mathrm{~cm}$ and, typically, the veneer snow is $20-40 \mathrm{~cm}$ deep as well. During autumn, the first few snowfalls may melt off from the tops of tussocks and leave pockets of new snow between the tussocks. Meltwater, draining from the tops, often saturates the snow between tussocks to produce icy zones.

After snow has filled the inter-tussock areas, subsequent snowfalls tend to drift over the tussock tops. Due in part to the uneven nature of the original snow surface, and in part to wind turbulence, the wind slabs that overlie the basal hoar tend to develop into sastrugi. Because of the micro-topography of the sastrugi surface, marked horizontal variability is created. Fine-grained, low-density snow collects in hollows. These deposits, when buried, metamorphose into laterally discontinuous depthhoar partings. Elsewhere wind slabs are adjacent, one on top of the other. As the winter progresses even dense wind slabs can begin to metamorphose into depth hoar. We have observed wind slabs as dense as $0.35 \mathrm{~g} \mathrm{~cm}^{-3}$ metamorphose into depth hoar by the end of the season. In other cases, wind slabs of density $0.40-0.45 \mathrm{~g} \mathrm{~cm}^{-3}$ have lasted intact from mid-December to the end of March.

Overall, the veneer facies can be characterized as one or more fine-grained, wind-packed layers overlying a basal depth-hoar layer. Late in the winter the basal depth-hoar layer is thicker because of the addition of metamorphosed wind slabs. Depth hoar densities range from 0.15 to $0.25 \mathrm{~g} \mathrm{~cm}^{-3}$, while medium-grained and wind-packed layers can range from 0.2 to $0.55 \mathrm{~g} \mathrm{~cm}^{-3}$. The mean veneer density is at its minimum in less windy areas. A good example is in the headwater region of Imnavait Creek $\left(68^{\circ} 37^{\prime} \mathrm{N}, 149^{\circ} 17^{\prime} \mathrm{W}\right)$ near Toolik Lake, which is dominated by katabatic flow north from the Brooks Range. In 1985 an average density of $0.25 \mathrm{~g} \mathrm{~cm}^{-3}$ was measured in the Imnavait watershed (Liston, 1986); 
Table 1. Mean depth, density, grain-size and strength of tundra and taiga snow

\begin{tabular}{|c|c|c|c|}
\hline Depth range & Mean density & Maximum density & Grain-size \\
\hline $\mathrm{m}$ & $\mathrm{g} \mathrm{cm}^{-3}$ & $\mathrm{~g} \mathrm{~cm}^{-3}$ & $\mathrm{~mm}$ \\
\hline
\end{tabular}

Taiga snow (mostly depth hoar)
$0.4-0.9$
0.23
0.3
$0.5-10$
low

Tundra snow

Veneer facies (depth-hoar and wind-packed)

\begin{tabular}{|c|c|c|c|c|}
\hline $0-0.6$ & $0.25-0.30$ & 0.55 & $0.5-10$ & variable \\
\hline New snow & 0.1 & & $0.5-1.0$ & low \\
\hline dium-grained & 0.2 & & $1-2$ & medium \\
\hline Wind slab & $0.4-0.5$ & & $0.5-1.0$ & high \\
\hline epth hoar & $0.15-0.25$ & & $5-10$ & low \\
\hline
\end{tabular}

Drift facies (all wind-packed)
$1-10$
0.38
0.55
$0.5-1.0$
high

Note: $\mathrm{g} \mathrm{cm}^{-3} \equiv \mathrm{tm}^{-3} \quad \mathrm{t}=$ metric ton $=10^{3} \mathrm{~kg}$.

in 1989 the average in this region was $0.28 \mathrm{~g} \mathrm{~cm}^{-3}$. Higher densities occur in the areas farther out on the Arctic coastal plain and along the coast, where the stronger eastwest winds predominate; there the average density generally exceeds $0.3 \mathrm{~g} \mathrm{~cm}^{-3}$. An example is a mean density of $0.324 \mathrm{~g} \mathrm{~cm}^{-3}$ measured in the Prudhoe Bay area (Benson and others, 1975).

\section{DRIFT FACIES OF THE TUNDRA SNOW}

A significant fraction (up to half) of the snow which is precipitated on the tundra is relocated by wind (Benson, 1982). Part of the relocated snow is lost by evaporation during transport (Tabler, 1975, 1976). This fraction depends on wind speed, the nature of the surface over

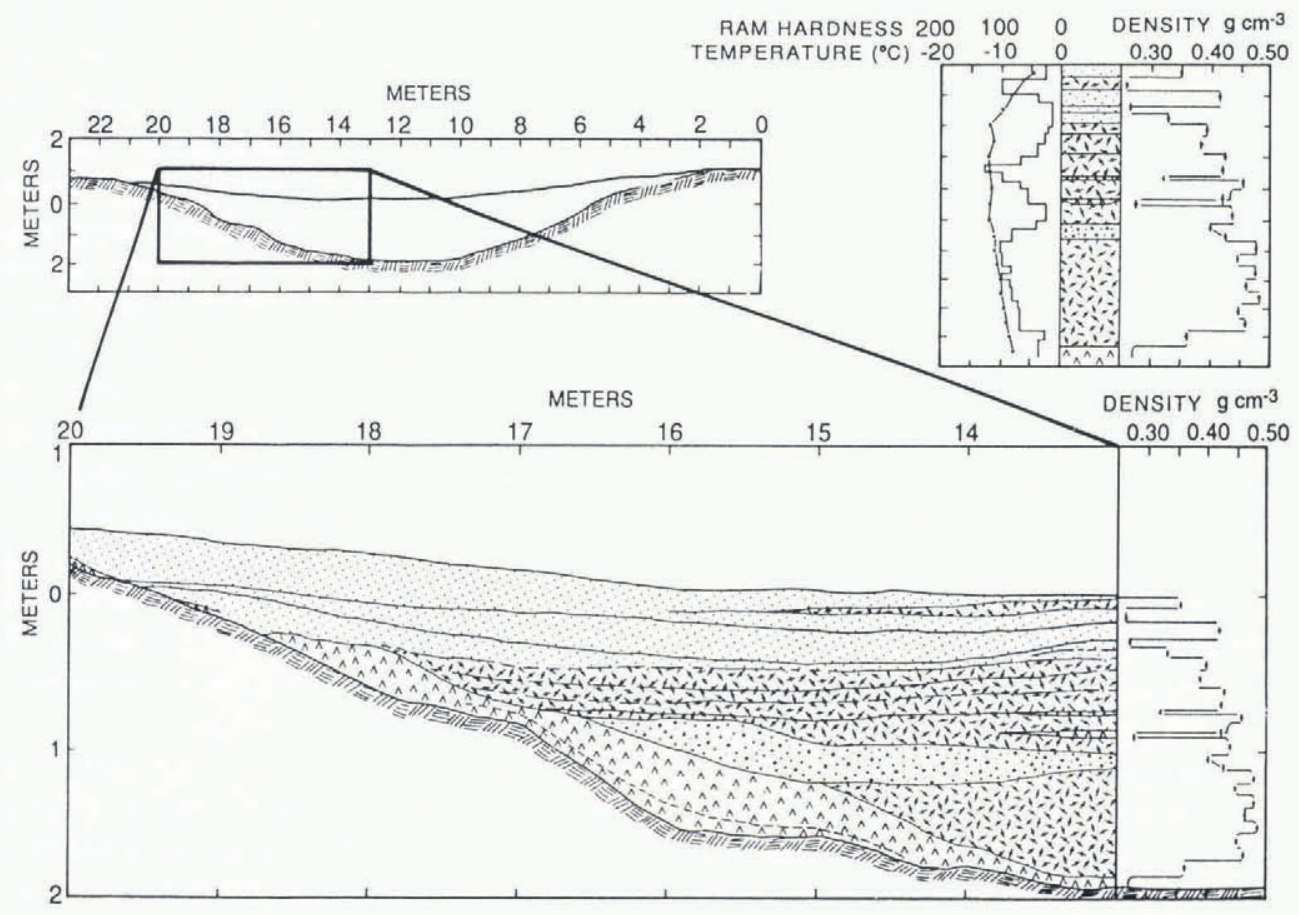

Fig. 2. Typical cross-section through a drift in the tundra snow cover near Lake Noluck in the north-central Brooks Range. Although this drift trap fills with snow during winter, the stratigraphy is similar to that in traps that do not fill, such as those at Meade River (Fig. 3). Density, temperature and Rammsonde hardness profiles measured at the $13 \mathrm{~m}$ point are shown at upper right. 


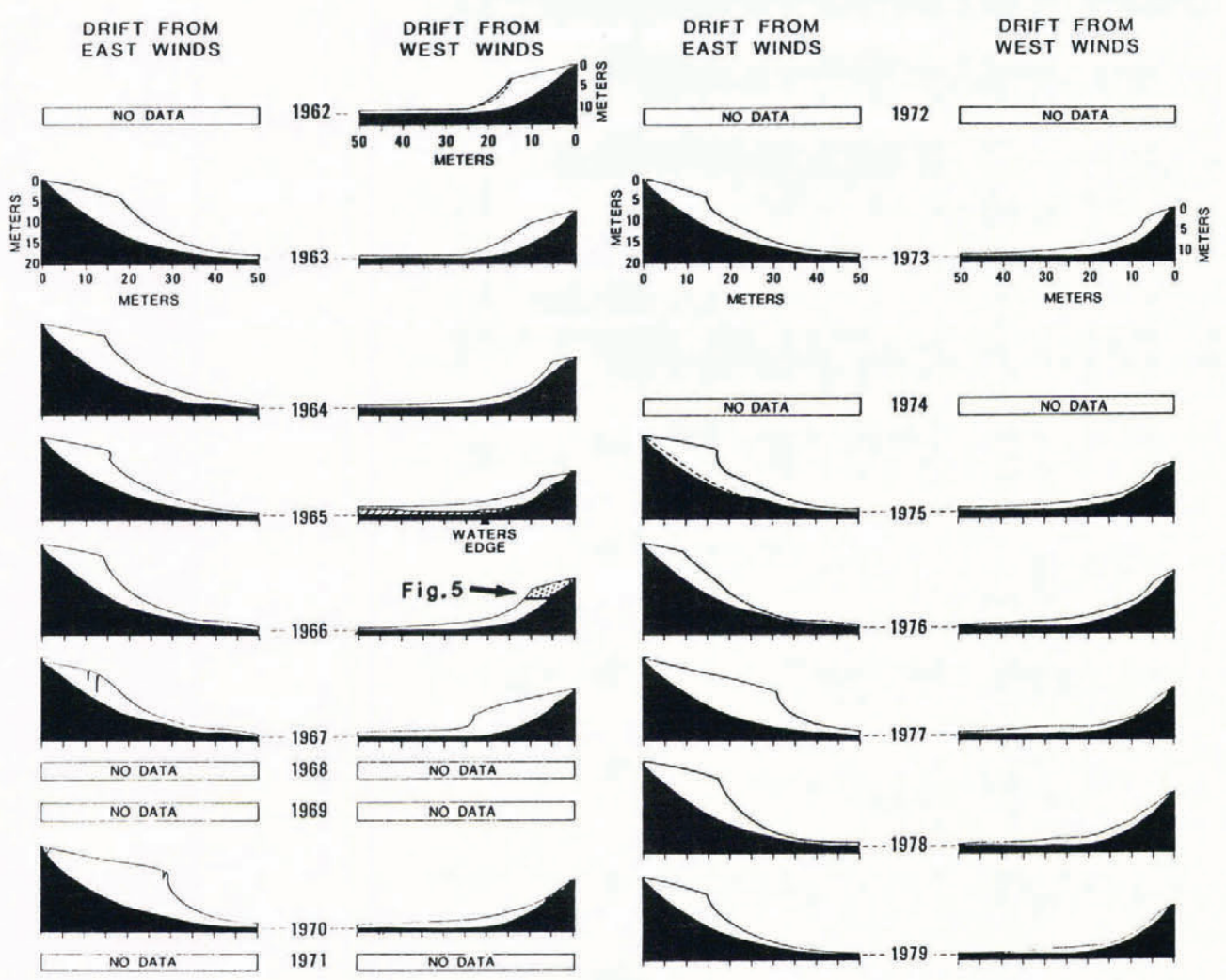

Fig. 3. Snow drifts from the east and west winds measured at the river bluffs at Atqasuk on the Meade River, approximately $95 \mathrm{~km}$ south-southwest of Barrow. Cross-sections are viewed from the north. The cross-sectional area and the mass (per lineal $m$ normal to the wind) are given in Table 2.

which the snow is blowing, the air temperature, and the fetch distance to the nearest drift trap. On the Arctic slope of Alaska this fraction remains to be determined. It may equal the amount lost by evaporation which occurs during snowmelt, which is in the range of $20-30 \%$ of the snowpack (Kane and others, 1991; Hinzman, 1990). Evaporative losses are significantly higher in windy areas where snow is thin. In the Lake Noluck region $\left(68^{\circ} 40^{\prime} \mathrm{N}\right.$, $160^{\circ} 00^{\prime} \mathrm{W}$ ) the snow on the tundra has been observed to disappear over large areas $\left(10^{3} \mathrm{~m}^{2}\right)$ before any water was present either on the tundra or in stream channels (Benson, 1969).

The fraction of transported snow deposited in drifts has been measured in carefully selected drift traps since 1962. These traps are natural features, such as stream channels, river banks and bluffs oriented normal to the wind. There are two types of traps: those which fill with snow during the winter and eventually cease to retain any subsequent material (Fig. 2); and those which have sufficient capacity to capture all transported snow (Figs 3, 4 and 5). We have measured both types, but concentrated on the latter because the drifts stored in them at the end of the winter represent the total winter's flux of wind-blown snow from a given wind direction. The drift surface profiles were measured by surveying from a bench mark, and the depths were measured by probing. Stratigraphy, density and temperature were measured in excavations. The measurements span 30 years to show year-to-year variability.

On most of the Arctic slope two primary wind directions are responsible for moving snow, and these are nearly $180^{\circ}$ apart (Conover, 1960; Benson, 1969; Wendler, 1978). They are the prevailing winds, from the east, and storm-winds from the west. Each year drift patterns remain the same but vary in size according to the quantity of snow available for transport. Drifts from the east winds are more nearly constant in size from year to year than are drifts from the west winds, which are associated with storms bringing new snow.

A pair of drift traps was selected in the vicinity of Atqasuk $\left(70^{\circ} 29^{\prime} \mathrm{N}, 157^{\circ} 25^{\prime} \mathrm{W}\right)$ on the Meade River about $95 \mathrm{~km}$ south-southwest of Barrow. The river banks are 10$20 \mathrm{~m}$ high and the meander loops provide exposure to wind drifting from all possible directions. Banks parallel to the two primary winds do not form snow drifts, but banks normal to them form large drifts each year (Benson, 1969, 1982). A summary of measurements of these drifts from 1962 to 1979 is presented in Figure 3 and Table 2. In general, the annual flux from the prevailing east winds is twice that of the west winds. However, during the 1966-67 winter, the west winds transported more snow than the prevailing easterly winds. This may have been the result of a few large storms combined with exceptional winds; the Barrow weather records for that winter show that the total snowfall was not exceptional. Much remains to be learned about the interaction between snow quantity and wind speed during storms and about the resulting drifts.

A drift trap in the Imnavait Creek watershed has also been studied to measure wind transport from the southerly winds which flow as katabatic drainage from the Brooks Range. The results from six years of measurement are summarized in Figure 4 and Table 3. The flux from the south winds is less than that of the primary east and west winds.

The boundary between the southerly flow, which 

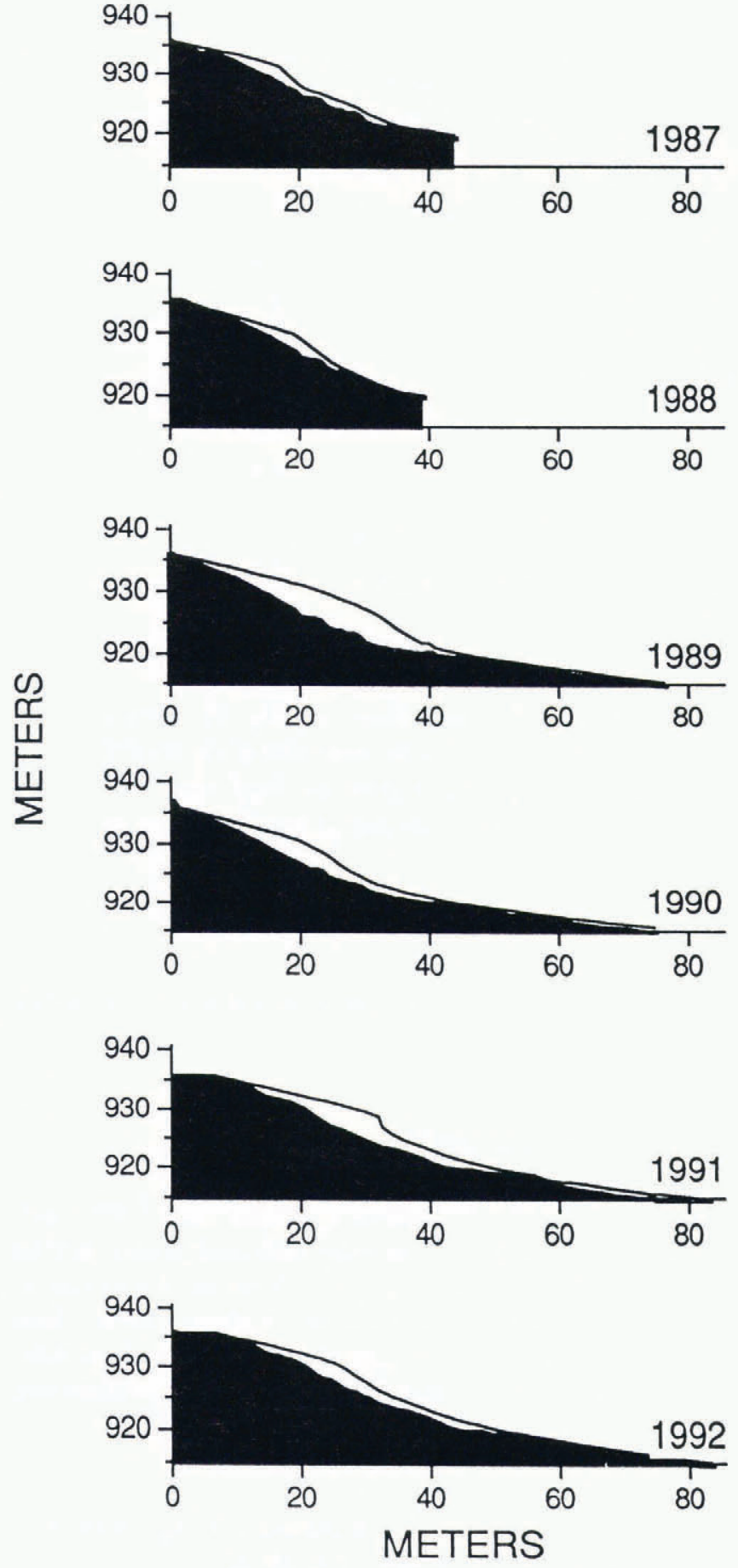

Fig. 4. Snow drifts from the south wind measured at an east-west trending bluff near Imnavait Creek, approximately $180 \mathrm{~km}$ south of Prudhoe Bay. Cross-sections are viewed from the east. The cross-sectional area and the mass (per lineal $m$ normal to the wind) are given in Table 3.

extends north from the Brooks Range, and the east-west winds which are the primary winds of the Arctic slope, has been identified in some regions but remains to be mapped in detail. South of Prudhoe Bay the transition is $160 \mathrm{~km}$ from the coast. Where large rivers flow north from the Brooks Range, the transition is displaced north.

The snow in both filled and unfilled drift traps differs in structure from the veneer facies. The drifts are often 10-20 times deeper than the adjacent veneer snow. The mean density of the drifts is higher (Table 1), and the total percentage of depth hoar is lower, generally confined to a thin zone at the base of the snow and to a few extremely thin partings (Fig. 2). In some cases, depth hoar is essentially absent from the drift stratigraphy. The reason for this absence of depth hoar is that the temperature gradients across the drift are greatly reduced due to the increased snow thickness (Fig. 5). Vertical temperature gradients measured across the tundra veneer snow are typically well in excess of the critical gradient necessary for depth-hoar metamorphism (Akitaya, 1974), but gradients across drifts may drop below the critical value. Also, wind-drifted layers deposited in the drift traps are often more dense than the comparable layer in the veneer, and hence more resistant to depth hoar metamorphism.

Cornices and cornice cracks (due to down-slope creep) are common structures in the drift facies. Figure 5 shows a cross-section through the first $10 \mathrm{~m}$ of the 1966 drift (Fig. 4) at Atqasuk. A buried cornice with a void space over $1 \mathrm{~m}$ deep can be seen in the figure. In general, each large wind storm results in the formation of a buried cornice. Also, it is common for the area upwind of a drift to be a region of scour. Consequently, strata within the drift are often discolored from dirt and organic material that has blown in with the snow.

The correlation of strata in drifts to strata in veneer facies is complicated. In general, the oldest strata in the

Table 2. Cross-sectional area and mass of drifts at Meade River, Alaska

\section{Drift from east winds Drift from west winds

$\begin{array}{ccccc}\text { Year Area } & \text { Mass } & \text { Area } & \text { Mass } & \text { Date } \\ & \mathrm{m}^{2} & 10^{3} \mathrm{~kg} \mathrm{~m}^{-1} & \mathrm{~m}^{2} & 10^{3} \mathrm{~kg} \mathrm{~m}^{-1}\end{array}$

$\begin{array}{rrrrrr}1962 & & & 99 & 38 & 3 \text { May } 1962 \\ 1962 & & & 94 & 36 & \text { n.d. } \\ 1963 & 192 & 73 & 98 & 37 & 13 \text { May } 1963 \\ 1964 & 166 & 63 & 60 & 23 & 8 \text { May } 1964 \\ 1964 & & & 49 & 19 & \text { n.d. } \\ 1965 & 161 & 61 & 96 & 36 & 22 \text { May } 1965 \\ 1966 & 144 & 55 & 84 & 32 & 29 \text { May } 1966 \\ 1967 & 127 & 48 & 154 & 59 & 18 \text { May } 1967 \\ 1970 & 280 & 106 & 78 & 30 & 23 \text { May } 1970 \\ 1973 & 137 & 52 & 80 & 30 & 14 \text { May } 1973 \\ 1975 & 182 & 69 & 66 & 25 & 17 \text { May } 1975 \\ 1975 & 159 & 60 & & & \text { n.d. } \\ 1976 & & & 55 & 21 & 16 \text { Apr } 1976 \\ 1976 & 116 & 44 & 64 & 24 & 28 \text { Apr } 1976 \\ 1977 & 267 & 101 & 63 & 24 & 6 \text { May } 1977 \\ 1978 & 167 & 63 & 64 & 24 & 13 \text { May } 1978 \\ 1979 & 131 & 50 & 46 & 17 & 8 \text { May } 1979\end{array}$

Mean

values $\begin{array}{llll}171 & 65 & 78 & 30\end{array}$




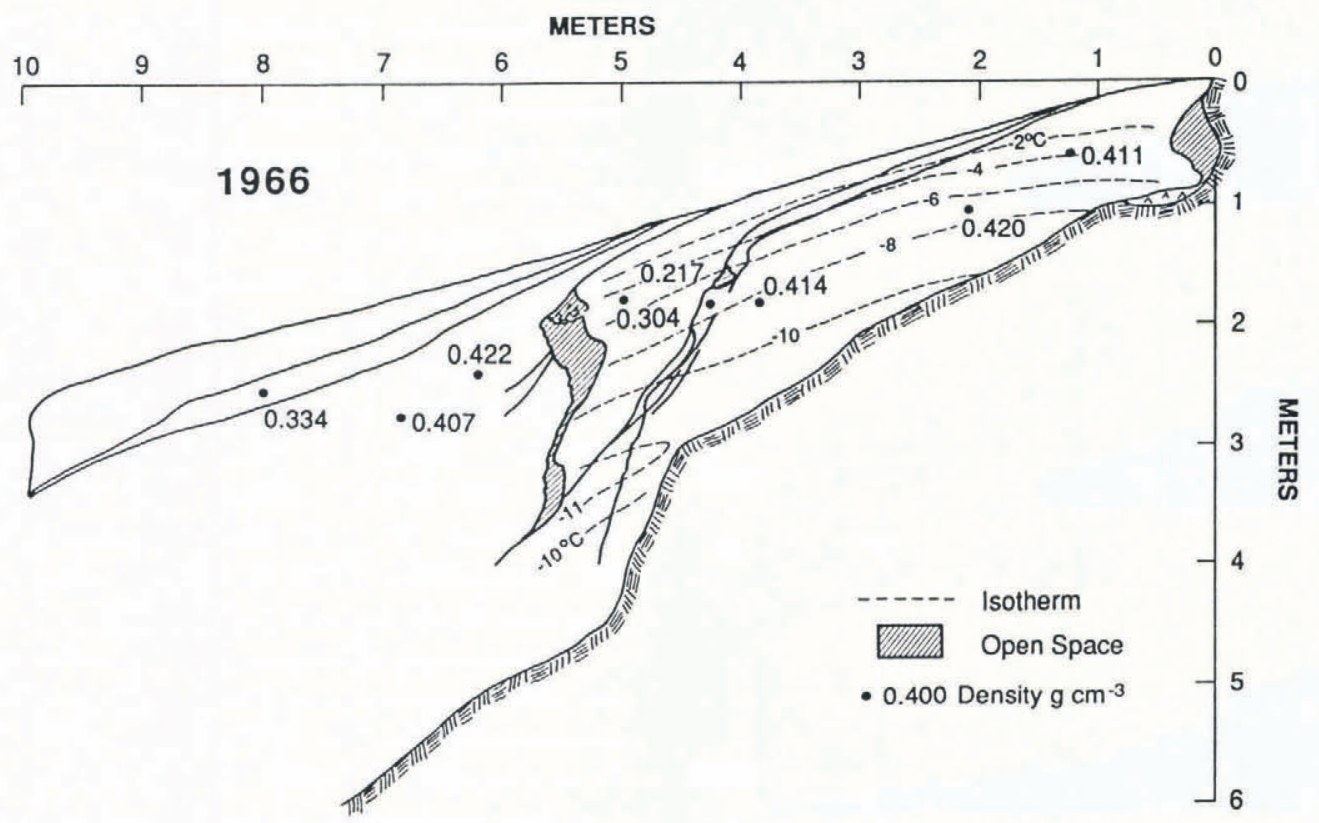

Fig. 5. Stratigraphic detail of the 1966 drift at the river bluffs at Atgasuk on the Meade River (see Fig. 3). Cornice cracks leave large voids in the snow. As the winter progresses, each new cornice is added to the outer edge of the existing cornice, so that the stratigraphy becomes progressively younger with increasing distance from the bluff edge. The temperature and density measurements were made in the pit wall as it was excavated across the part of the drift outlined in Fig. 3.

veneer (at the base of the snow) correlates with the farthest upwind unit in the drift. Increasing height in the veneer stratigraphic column corresponds with increasing distance down the dip slope of the drift surface. However, units in the drift often have no analog in the veneer snow which has been partly blown away. It is also possible for several snowfalls to occur with little or no wind, and then all be removed and deposited as a single drift unit during the next wind storm.

\section{RECOMMENDATIONS}

Much remains to be learned about tundra snow. The Arctic slope is underlain by continuous permafrost so snowmelt and runoff, together with evaporation, are major components of the hydrological budget. Yet the quantity of precipitation which comes in the form of snow has been underestimated by a factor of about three, and the evaporation losses, both during transport as windblown snow and during the melt season, are poorly known (Benson, 1982; Kane and others, 1991). The distribution of wind-blown snow and its year-to-year variability are also poorly known. We recommend the following:

1. Continue refinements in estimating the precipitation which comes as snow in the Arctic.

2. Continue attempts to determine the evaporative losses from snow while it is in the air as wind-blown snow and while it is on the ground during the melt season.

3. Determine the boundaries of wind regimes which control the transport of snow.

4. Continue attempts to understand the correlations between veneer snow and drift snow on the Arctic slope.

\section{ACKNOWLEDGMENTS}

We wish to thank the following people (listed alphabetically) who have helped measure drift and veneer profiles all across Alaska from Point Lay to Venetie: Karl Francis, Harold Garbiel, Tom George, Robert Gieck, Don Grybeck, Larry Hinzman, Jon Holmgren, Elizabeth Lily, Glen Liston, Peter MacKeith, M. (Pete) Martinelli,

Table 3. Cross-sectional area and mass in drift north of S-2 monument at Imnavait Creek, Alaska

$\begin{array}{lrcr}\text { Year } & \text { Area } & \text { Mass } & \text { Date } \\ & \mathrm{m}^{2} & 10^{3} \mathrm{~kg} \mathrm{~m}^{-1} & \\ & & & \\ & & & \\ 1987 & 52 & 20 & 16 \text { May } 1987 \\ 1988 & 29 & 11 & 17 \text { May 1988 } \\ 1989 & 122 & 28 & \text { 17 May 1989 } \\ 1990 & 73 & 21 & \text { 9 May 1990 } \\ 1991 & 54 & 24 & \text { 22 Mar 1991 } 1992 \\ 1992 & 63 & & \end{array}$

Mean

values

66 
Daniel Solie, Barry Santana, R.A. Schmidt, Ronald Tabler, and Matt Zukowski. Special thanks go to Ron Tabler, the Blizzard Wizard, for helping us clarify our thinking about problems of the wind-blown tundra snow. This work has been supported by grants from the Department of Energy (DOE grant number DE-FG0684ER60245), the National Science Foundation (NSF grants: G-22224, GV-29342, DPP 79-26425, and DPP 9002345), and the Naval Arctic Research Laboratory at Barrow, Alaska (ONR Task N. R. 307-272); by State of Alaska Funds; and from U.S. Army Cold Regions Research and Engineering Laboratory AT-42 /S-26 program. Glaciological Research at the University of Alaska received its initial support from a grant by $\mathrm{Dr}$ Terris Moore, former president of the University of Alaska.

\section{REFERENCES}

Akitaya, E. 1974. Studies on depth hoar. Contrib. Inst. Low Temp. Sci., Ser. A 26.

Benson, C. S. 1962. Stratigraphic studies of the snow and firn of the Greenland ice sheet. SIPRE Res. Rep. 70.

Benson, C. S. 1967. Polar regions snow cover. In Ôura, H., ed. Physics of snow and ice. Vol. 1, Part 2. Sapporo, Hokkaido University, Institute of Low Temperature Science, 1039-1063.

Benson, C. S. 1969. The seasonal snow cover of Arctic Alaska. Arctic Institute of North America Research Paper 51.

Benson, C.S. 1982. Reassessment of winter precipitation on Alaska's Arctic slope and measurements on the flux of wind blown snow. Fairbanks, University of Alaska. Geophysical Institute. (Report UAG-R 288.)

Benson, C., B. Holmgren, R. Timmer, G. Weller and S. Parrish. 1975. Observations on the seasonal snow cover and radiation climate at Prudhoe Bay, Alaska during 1972. Biol. Pap. Univ. Alaska. Spec. Rep. 2, 12-50.
Conover, J.H. 1960. Macro- and micro-climatology of the Arctic slope of Alaska. U.S. Quartermaster Research and Engineering Center. Environmental Protection Research Division. Technical Report EP-139.

Hinzman, L.D. 1990. The interdependence of the thermal and hydrologic processes of an Arctic watershed and their response to climate change. (Ph.D. thesis, University of Alaska, Fairbanks.)

Kane, D. L., L. D. Hinzman, C.S. Benson and G.E. Liston. 1991. Snow hydrology of a headwater Arctic basin 1. Physical measurements and process studies. Water Resour. Res., 27(6), 1099-1109.

Liston, G.E. 1986. Seasonal snowcover of the foothills region of Alaska's Arctic slope: a survey of properties and processes. (M.S. thesis, University of Alaska, Fairbanks.)

Pruitt, W., Jr. 1970. Some ecological aspects of snow. In Ecology of the subarctic regions. Proceedings of the Helsinki Symposium. Paris, UNESCO, 83-99.

Sturm, M. 1991. The role of thermal convection in heat and mass transport in the subarctic snow cover. CRREL Rep. 91-19.

Tabler, R.D. 1975. Estimating the transport and evaporation of blowing snow. Proceedings of the Great Plains Agricultural Council. Publication 73, 85-104.

Tabler, R.D. 1976. Evaporation losses of windblown snow, and the potential for recovery. Proc. West. Snow Conf. 41st Annual Meeting, 75-79.

Trabant, D. and C. S. Benson. 1972. Field experiments on the development of depth hoar. Geol. Soc. Am. Mem. 135, 309-322.

Wendler, G. 1978. Snow blowing and snow fall on the North Slope, Alaska. Fairbanks, University of Alaska. Geophysical Institute. (Report UAG R-259.)

The accuracy of references in the text and in this list is the responsibility of the authors, to whom queries should be addressed. 